University of Nebraska - Lincoln

DigitalCommons@University of Nebraska - Lincoln

\title{
Tillage, Nitrogen, and Cropping System Effects on Soil Carbon Sequestration
}

Ardell Halvorson

USDA, Ardell.Halvorson@ars.usda.gov

Brian J. Wienhold

University of Nebraska-Lincoln, Brian.Wienhold@ars.usda.gov

Alfred L. Black

USDA-ARS

Follow this and additional works at: https://digitalcommons.unl.edu/usdaarsfacpub

Halvorson, Ardell; Wienhold, Brian J.; and Black, Alfred L., "Tillage, Nitrogen, and Cropping System Effects on Soil Carbon Sequestration" (2002). Publications from USDA-ARS / UNL Faculty. 1219.

https://digitalcommons.unl.edu/usdaarsfacpub/1219

This Article is brought to you for free and open access by the U.S. Department of Agriculture: Agricultural Research Service, Lincoln, Nebraska at DigitalCommons@University of Nebraska - Lincoln. It has been accepted for inclusion in Publications from USDA-ARS / UNL Faculty by an authorized administrator of DigitalCommons@University of Nebraska - Lincoln. 


\title{
Tillage, Nitrogen, and Cropping System Effects on Soil Carbon Sequestration
}

\author{
Ardell D. Halvorson,* Brian J. Wienhold, and Alfred L. Black
}

\begin{abstract}
Soil $\mathrm{C}$ sequestration can improve soil quality and reduce agriculture's contribution to $\mathrm{CO}_{2}$ emissions. The long-term (12 yr) effects of tillage system and $\mathbf{N}$ fertilization on crop residue production and soil organic C (SOC) sequestration in two dryland cropping systems in North Dakota on a loam soil were evaluated. An annual cropping (AC) rotation [spring wheat (SW) (Triticum aestivum L.)-winter wheat (WW)-sunflower (SF) (Helianthus annuus L.)] and a spring wheat-fallow (SW-F) rotation were studied. Tillage systems included conventional-till (CT), minimum-till (MT), and no-till (NT). Nitrogen rates were 34, 67, and $101 \mathrm{~kg} \mathrm{~N} \mathrm{ha}^{-1}$ for the $\mathrm{AC}$ system and 0,22 , and $45 \mathrm{~kg} \mathrm{~N} \mathrm{ha}^{-1}$ for the SW-F system. Total crop residue returned to the soil was greater with $A C$ than with SW-F. As tillage intensity decreased, SOC sequestration increased (NT $>$ MT $>$ CT) in the AC system but not in the SW-F system. Fertilizer $N$ increased crop residue quantity returned to the soil, but generally did not increase SOC sequestration in either cropping system. Soil bulk density decreased with increasing tillage intensity in both systems. The results suggest that continued use of a crop-fallow farming system, even with NT, may result in loss of SOC. With NT, an estimated $233 \mathrm{~kg} \mathrm{C} \mathrm{ha}^{-1}$ was sequestered each year in $\mathrm{AC}$ system, compared with $25 \mathrm{~kg} \mathrm{C} \mathrm{ha}^{-1}$ with MT and a loss of $141 \mathrm{~kg} \mathrm{C} \mathrm{ha}^{-1}$ with CT. Conversion from cropfallow to more intensive cropping systems utilizing NT will be needed to have a positive impact on reducing $\mathrm{CO}_{2}$ loss from croplands in the northern Great Plains.
\end{abstract}

$\mathrm{N}$ O-TILL AND MT SYSTEMS have allowed producers in the semi-arid Great Plains to intensify the frequency of cropping when compared with the traditional crop-fallow system (Aase and Schaefer, 1996; Farahani et al., 1998; Halvorson, 1990; Halvorson and Reule, 1994; Halvorson et al., 1999a,b, 2000a). Deibert et al. (1986) and Peterson et al. (1996) point out that more continuous cropping and less crop-fallow is needed in the Great Plains to attain more efficient use of limited water supplies. Cihacek and Ulmer (1995) point out that more intensive cropping systems than crop-fallow along with reduced tillage is needed to prevent the loss of SOC from Great Plains soils. The fallow period represents a time of high microbial activity and decomposition of soil organic matter with no input of crop residue. Annual cropping reduces the amount of time decomposition is occurring without crop residue inputs. Fallow also represents a time when the soil is susceptible to wind erosion which is another major loss mechanism for soil organic matter in the northern Great Plains (Haas et al., 1974).

A.D. Halvorson, USDA-ARS, P.O. Box E, Fort Collins, CO 80522; B.J. Wienhold, USDA-ARS, 119 Keim Hall, East Campus, Univ. of Nebraska, Lincoln, NE 68583; A.L. Black, USDA-ARS, retired, 226 E. Circle Dr., Canon City, CO 81212. Contribution from USDA-ARS. The USDA offers its programs to all eligible persons regardless of race, color, age, sex, or national origin, and is an equal opportunity employer. Received 9 Apr. 2001. *Corresponding author (adhalvor@ lamar.colostate.edu).

Published in Soil Sci. Soc. Am. J. 66:906-912 (2002).
With increased cropping intensity, one would expect that more crop residue and $\mathrm{C}$ would be added to the soil than with a crop-fallow system (Campbell et al., 1995, 2000b; Janzen et al., 1998a; Peterson et al., 1998). As the amount of crop residue returned to the soil is increased, SOC sequestration is expected to increase if the residue $\mathrm{C}$ is not lost as $\mathrm{CO}_{2}$ to the atmosphere because of tillage induced decomposition (Larney et al., 1997; Reicosky, 1997a,b). Research in the Great Plains has shown that SOC sequestration is enhanced by $\mathrm{N}$ fertilization (Campbell and Zentner, 1993; Campbell et al., 2000a; Halvorson et al., 1999c, 2000c; Nyborg et al., 1995). Campbell et al. (1996, 1997, 1998) reported increased SOC levels as fallow frequency and tillage intensity decreased within Canadian Prairie Province cropping systems in the northern Great Plains. Bauer and Black (1994) demonstrated the value of SOC in enhancing soil water-soil fertility-crop productivity relationships. The benefit of increasing SOC is not only improved soil structure and water-nutrient relationships, but includes the ability to store $\mathrm{C}$ in the soil to reduce atmospheric $\mathrm{CO}_{2}$, a greenhouse gas (Janzen et al., 1999; Lal et al., 1998, 1999).

Bauer and Black (1981) pointed out the lack of longterm cropping systems data evaluating SOC sequestration in the northern Great Plains. In 1983, A.L. Black, USDA-ARS, at Mandan, ND initiated a long-term cropping system study to evaluate the influence of tillage and $\mathrm{N}$ fertility level on crop yields and soil $\mathrm{C}$ and $\mathrm{N}$ changes within SW-F and annual cropping (SW-WWSF) rotations (Black and Tanaka, 1997). Grain yields for this study have been reported by Halvorson et al. (1999a,b, 2000a,b). Since initiation of this study, numerous Canadian Prairie Province studies have reported on the effects of tillage system, fertility, and crop rotation on SOC sequestration as summarized by Janzen et al. (1998b). Peterson et al. (1998) summarized the positive influences of reduced tillage and intensified cropping systems on soil C in the U.S. Great Plains. No dryland studies on SOC sequestration were found in the northern Great Plains that included sunflower in the intensive crop rotation. This paper reports on the long-term effects of tillage system (CT, MT, and NT) and N fertilizer rate on crop residue production and SOC sequestration within two dryland cropping systems (SW-WW-SF and SW-F) located in the U.S. northern Great Plains.

\section{MATERIALS AND METHODS}

The study was initiated in 1984 on a Temvik-Wilton silt loam soil (fine-silty, mixed, superactive, frigid Typic and Pachic Haplustolls) with a 2 to $4 \%$ southeasterly slope located about

Abbreviations: AC, annual crop; CT, conventional-till; F, fallow; LSD least significant difference; MT, minimum-till; NT, no-till; $D_{\mathrm{b}}$, soil bulk density; SF, sunflower; SOC, soil organic C; SW, spring wheat; WW, winter wheat. 
$5 \mathrm{~km}$ southwest (lat. $46^{\circ} 46^{\prime} 25^{\prime \prime} \mathrm{N}$, long. $100^{\circ} 57^{\prime} 7^{\prime \prime} \mathrm{W}$ ) of Mandan, ND. The soil was fairly uniform over the research site. The soil was broken out of native sod in about 1951. The area was cropped to silage corn (Zea mays L.) and SW until 1982, with occasional years of summer fallow following SW. No set crop rotation was followed by the farmer during this 32-yr cropping period, but silage corn was produced more frequently than SW. Silage corn yields usually ranged from 18 to $22 \mathrm{Mg} \mathrm{ha}^{-1}$ and SW yields from 1300 to $1700 \mathrm{~kg} \mathrm{ha}^{-1}$. A tandem disk was used as the primary tillage implement during noncrop periods to control weeds. Planting of both crops was with a plow-packer-drill combination. Tillage depth with the plow was generally $<15 \mathrm{~cm}$, with all surface crop residue buried after the planting operation. Little, if any, $\mathrm{N}$ fertilizer had been applied during the 33-yr cropping period prior to 1984 . Some $\mathrm{P}$ fertilizer had been applied by the farmer. At the initiation of this study, $45 \mathrm{~kg} \mathrm{P} \mathrm{ha}^{-1}$ was broadcast applied over the entire study area to eliminate $\mathrm{P}$ deficiency in 1984. No more fertilizer P was applied to the plot area during the study period. Unfertilized sunflower was grown on the entire plot area in 1983 to establish uniform soil water and $\mathrm{N}$ levels.

An AC rotation (SW-WW-SF) and a SW-F rotation were managed under three tillage systems, CT, MT, and NT. Hardred wheats and oil sunflowers were grown in the rotations. The SW and SF were planted with no-till disk-opener planters and the WW with a no-till narrow-hoe opener type planter. Nitrogen fertilizer was applied in early spring each year to each crop as a broadcast application of $\mathrm{NH}_{4} \mathrm{NO}_{3}$ at rates of 34,67 , and $101 \mathrm{~kg} \mathrm{~N} \mathrm{ha}^{-1}$ in the annual cropping rotation and 0,22 , and $45 \mathrm{~kg} \mathrm{~N} \mathrm{ha}^{-1}$ in the SW-F rotation, except for 1991 and 1992, when no $\mathrm{N}$ was applied because of a build-up of residual soil $\mathrm{NO}_{3}-\mathrm{N}$ because of drought conditions and low yields from 1988 through 1990 . The total quantity of $\mathrm{N}$ applied during the 12 yr was 336,672 , and $1008 \mathrm{~kg} \mathrm{~N}^{-1}$ for the AC 34,67 , and $101 \mathrm{~kg} \mathrm{~N}^{-1}$ treatments, respectively, and 112 and $224 \mathrm{~kg} \mathrm{~N}^{-1}$ for the SW-F 22 and $45 \mathrm{~kg} \mathrm{~N} \mathrm{ha}^{-1}$ treatments, respectively.

Each main block of the study was 137.2 by $73.1 \mathrm{~m}$ in size. Tillage plots $(45.7$ by $73.1 \mathrm{~m})$ were oriented in a north-south direction and $\mathrm{N}$ plots (137.2 by $24.4 \mathrm{~m}$ ) in an east-west direction across tillage plots with individual plot size being 45.7 by $24.4 \mathrm{~m}$. Triplicate sets of AC plots (SW-WW-SF, WW-SF-SW, and SF-SW-WW crop sequences) and duplicate sets of SWF plots (SW-F and F-SW sequences) were established in 1984 to allow all phases of the rotations to be represented each year. The experimental design was a strip-split plot with tillage and $\mathrm{N}$ rate treatments stripped with three replications.

In the AC system, the CT treatments were generally disked once in the fall following harvest and prior to spring planting with generally $<30 \%$ surface residue cover at planting. Minimum-till treatments were generally undercut once with a sweep plow at a shallow depth $(<7.5 \mathrm{~cm})$ following harvest and again prior to spring planting with 30 to $60 \%$ residue cover at planting. No-till treatments generally received one application of glyphosate [ $N$-(phosphonomethyl)glycine] herbicide to control fall weed growth after harvest and prior to spring planting with generally $>60 \%$ surface residue cover at planting.

In the SW-F system, the fallow period began in August or September each year following SW harvest and continued until SW planting 20 to 21 mo later. The CT treatments were generally not tilled in the fall following SW harvest. Tillage operations for the fallow period generally began the following spring and summer, with one shallow $(<8 \mathrm{~cm})$ tillage operation with a sweep plow just prior to SW planting. Residue cover was generally $<30 \%$ at planting. A burn-down herbicide was generally applied in mid to late July during the summer of fallow to eliminate weeds and help maintain surface residue cover in the CT treatment by reducing the number of tillage operations. All tandem disk operations were performed at a depth of 8 to $12 \mathrm{~cm}$. Minimum-till treatments were generally not tilled in the fall following SW harvest, but were tilled once with a sweep plow the following spring. Burn-down herbicide applications were made as needed throughout the fallow period with one sweep plow operation just prior to SW planting. Residue cover was 30 to $60 \%$ at planting. All sweep plow operations were performed at a shallow depth $(<8 \mathrm{~cm})$. Notill treatments received burn-down herbicide applications as needed to control weed growth during the fallow period. Residue cover was generally $>60 \%$ at planting.

Spring-applied herbicides were used to control weeds within the growing crop in both cropping systems. The grain yields and production details have been reported by Halvorson et al. (1999a,b; 2000a,b). The total crop residue amount and total residue $\mathrm{N}$ presented here are the average of the $\mathrm{SW}, \mathrm{WW}$, and SF crops grown in the triplicate sets of AC plots over 12 yr. This was done to obtain an overall impact of the cropping system, tillage and $\mathrm{N}$ treatments on SOC sequestration.

Annual precipitation at the research site from 1984 through 1996 varied from a low of $205 \mathrm{~mm}$ in 1988 to a high of 659 $\mathrm{mm}$ in 1993 (Halvorson et al., 2001). The average annual precipitation during the study at the research site was 418 $\mathrm{mm}$, slightly more than the 82 -yr average of $409 \mathrm{~mm}$ at the nearby Northern Great Plains Research Laboratory, Mandan, ND. Monthly precipitation deviated greatly from the $13-\mathrm{yr}$ average monthly precipitation. Three consecutive years, 1988 to 1990 , were droughty with reduced grain yields (Halvorson et al., 1999a,b; 2000a,b). Annual precipitation in 1986, 1993 , 1994, and 1995 was above the average for the research site.

Yearly crop residue samples were collected at harvest of each crop and analyzed for $\mathrm{N}$ content using a wet-acid digest procedure (Lachat Instrument, 1992). Samples were ground to pass a $0.85-\mathrm{mm}$ screen prior to analysis. In 1994 and 1996 , crop residue $\mathrm{N}$ and $\mathrm{C}$ were determined by dry combustion with a Carlo-Erba ${ }^{1} \mathrm{C}-\mathrm{N}$ analyzer (Haake Buchler Instruments, Inc., Saddle Brook, NJ) (Schepers et al., 1989). The total amount of residue $\mathrm{N}$ returned to the soil in each cropping system was determined.

Soil samples, four 3-cm diam. cores per plot, were collected at random from each tillage and $\mathrm{N}$ fertilizer treatment of each rotation phase following harvest of each crop in the fall of 1996, including the fallow phase of the SW-F plots. Samples were collected from the 0- to 7.6-, 7.6- to 15.2-, and 15.2- to $30.5-\mathrm{cm}$ soil depths. After the soils were dried and ground, a $0.1 \mathrm{M} \mathrm{HCl}$ fizz-test was done on each sample to verify that $\mathrm{CO}_{3}-\mathrm{C}$ was not present. Each soil core was analyzed separately for total soil $\mathrm{N}$ and $\mathrm{C}$ with the Carlo-Erba $\mathrm{C}-\mathrm{N}$ analyzer. Soil bulk density $\left(D_{\mathrm{b}}\right)$ was determined for each sampling depth in each plot using a soil-core method (Culley, 1993).

Soil organic C reported for 1983 by Black and Tanaka (1997) was determined by the Walkley-Black method (Peech et al., 1947) on soil samples (two cores for each soil depth) collected from each tillage treatment of each main block (all rotation phases) in the study. Soil $D_{\mathrm{b}}$ reported by Black and Tanaka (1997) was determined in 1990 similarly to the method used in the 1996 soil sampling in each of the tillage and $\mathrm{N}$ treatments from all rotation phases. Because a CT production system was used prior to initiation of the study in 1984, the average soil $D_{\mathrm{b}}$ value reported for each soil depth in 1990 for

\footnotetext{
${ }^{1}$ Trade and company names are included for the benefit of the reader and do not imply endorsement or preferential treatment of the product by USDA-ARS.
} 
Table 1. Total crop residue and residue $\mathbf{N}$ returned to the soil during $12 \mathrm{yr}$ for a spring wheat-fallow (SW-F) and an annual cropping (spring wheat-winter wheat-sunflower) rotation as a function of tillage and $\mathrm{N}$ rate treatments at Mandan, ND.

\begin{tabular}{|c|c|c|c|c|}
\hline \multirow[b]{2}{*}{ Treatment } & \multicolumn{2}{|c|}{ SW-F rotation } & \multicolumn{2}{|c|}{ Annual crop rotation } \\
\hline & $\begin{array}{c}\text { Crop } \\
\text { residue }\end{array}$ & Residue N & $\begin{array}{c}\text { Crop } \\
\text { residue }\end{array}$ & Residue $\mathbf{N}$ \\
\hline & $\operatorname{Mgha}^{-1}$ & $\operatorname{kg~N} \mathbf{h a}^{-1}$ & $\operatorname{Mgha}^{-1}$ & $\operatorname{kg~N} \mathbf{h a}^{-1}$ \\
\hline \multicolumn{5}{|l|}{ Tillage } \\
\hline CT & 21.8 & 146 & 35.7 & 301 \\
\hline MT & 21.5 & 142 & 38.7 & 312 \\
\hline NT & 20.2 & 131 & 40.2 & 289 \\
\hline $\mathbf{L S D}_{0.05}$ & 0.7 & 9 & 1.2 & N.S. \\
\hline Prob $>$ F & 0.01 & 0.02 & $<0.01$ & 0.09 \\
\hline \multicolumn{5}{|l|}{ N Rate $\dagger$} \\
\hline N1 & 20.1 & 125 & 35.2 & 241 \\
\hline N2 & 21.2 & 140 & 39.0 & 308 \\
\hline N3 & 22.2 & 153 & 40.5 & 353 \\
\hline $\mathbf{L S D}_{0.05}$ & 1.3 & 12 & 1.2 & 12 \\
\hline Prob $>\mathbf{F}$ & 0.03 & 0.01 & $<0.01$ & $<0.01$ \\
\hline
\end{tabular}

$\dagger \mathrm{N1}=34, \mathrm{~N} 2=67, \mathrm{N3}=101 \mathrm{~kg} \mathrm{~N}^{\mathrm{N}} \mathrm{h}^{-1}$ for SW-WW-SF rotation; $\mathrm{N1}=$ $0, \mathrm{~N} 2=22, \mathrm{N3}=45 \mathrm{~kg} \mathrm{~N}^{-1}$ for SW-F rotation.

the CT treatments of SW-F (Black and Tanaka, 1997) were used to calculate an estimated mass of SOC present in fall of 1983.

Analysis of variance procedures were conducted using SAS statistical procedures (SAS Institute Inc., 1991). Each cropping system was analyzed separately. All differences discussed are significant at the $P \leq 0.05$ probability level unless otherwise stated. A least significant difference (LSD) was calculated only when the analysis of variance F-test was significant at the $P \leq 0.05$ probability level.

\section{RESULTS AND DISCUSSION}

\section{Crop Residue}

The total crop residue returned to the soil surface during $12 \mathrm{yr}$ (six crops) in the SW-F rotation was less with NT than with CT and MT systems (Table 1). In contrast, the $\mathrm{AC}$ rotation total crop residue returned to the soil during $12 \mathrm{yr}$ or 12 crops increased with decreasing tillage intensity $(\mathrm{NT}>\mathrm{MT}>\mathrm{CT})$. Residue returned to the soil with AC rotation was 164, 180, and 199\% of that with SW-F rotation for the CT, MT, and NT treatments, respectively. The greater level of crop residue with the AC rotation resulted because six more crops were grown in $12 \mathrm{yr}$ with this rotation compared with the SW-F rotation.

The total amount of $\mathrm{N}$ in the residue returned to the soil was greater with CT and MT than with NT for the SW-F rotation (Table 1). Total residue $\mathrm{N}$ for the AC rotation followed the same trends for tillage treatments as with SW-F rotation with differences in total residue $\mathrm{N}$ being significant at $P=0.09$. Although more residue was produced with NT in the AC rotation than with MT or CT, residue $\mathrm{N}$ tended to be lower with NT. This probably reflects the lower level of available soil $\mathrm{N}$ with the NT system than with CT and MT (Halvorson et al., 1999a,b, 2000a, 2001).

Total crop residue and total residue $\mathrm{N}$ returned to the soil generally increased with increasing $\mathrm{N}$ rate for both cropping rotations (Table 1); however, in the SW-F cropping system, differences in crop residue $\mathrm{N}$ were only significant between the 0 and $45 \mathrm{~kg} \mathrm{~N}^{-1}$ treatments. Nitrogen fertilization increased residue levels more in the AC rotation, which had higher $\mathrm{N}$ rates, than with the SW-F rotation. The amount of residue $\mathrm{N}$ returned to the soil with the AC rotation was more than double that with the SW-F rotation when averaged across $\mathrm{N}$ rates.

\section{Soil Carbon}

Soil organic C mass in the soil depths sampled was not significantly affected by tillage or $\mathrm{N}$ treatment in the SW-F rotation after $12 \mathrm{yr}$ (Table 2). In contrast, SOC mass in the $0-$ to $7.6-\mathrm{cm}$ soil depth increased as tillage intensity decreased within the AC rotation. This reflects the increasing level of crop residue returned to the soil with decreasing tillage intensity in $\mathrm{AC}$ rotation (Table 1). As tillage intensity increases, crop residuesoil contact is increased and incorporated residues are placed into moister conditions than those left on the soil surface. In addition, tillage creates a more oxidative soil environment resulting in more rapid decomposition of crop residues and soil organic matter (Doran, 1980). Although $\mathrm{N}$ fertilization increased the level of residue returned to the soil, SOC sequestration was not affected by $\mathrm{N}$ fertilization in the AC rotation, except for a signifi-

Table 2. Soil organic C (SOC) by soil depth after $12 \mathrm{yr}$ in a spring wheat-fallow (SW-F) and an annual crop (spring wheat-winter wheatsunflower) rotation as a function of tillage and $\mathrm{N}$ rate treatments at Mandan, ND.

\begin{tabular}{|c|c|c|c|c|c|c|}
\hline \multirow[b]{3}{*}{ Treatment } & \multicolumn{3}{|c|}{ SW-F rotation } & \multicolumn{3}{|c|}{ Annual crop rotation } \\
\hline & \multicolumn{3}{|c|}{ Soil depth, cm } & \multicolumn{3}{|c|}{ Soil depth, cm } \\
\hline & $0-7.6$ & $7.6-15.2$ & $15.2-30.4$ & $0-7.6$ & $7.6-15.2$ & $15.2-30.4$ \\
\hline & & & $-\mathbf{S}$ & -1 & 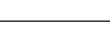 & - \\
\hline \multicolumn{7}{|l|}{ Tillage } \\
\hline CT & 16.3 & 19.9 & 29.4 & 18.4 & 19.3 & 26.4 \\
\hline MT & 17.8 & 19.8 & 27.9 & 19.5 & 20.2 & 29.2 \\
\hline NT & 17.4 & 18.2 & 27.3 & 20.8 & 21.4 & 28.4 \\
\hline $\mathbf{L S D}_{0.05}$ & N.S. & N.S. & N.S. & 1.5 & 1.0 & N.S. \\
\hline Prob $>$ F & 0.15 & 0.07 & 0.74 & 0.03 & 0.01 & 0.13 \\
\hline \multicolumn{7}{|l|}{ N Rate } \\
\hline N1 & 16.9 & 19.0 & 28.1 & 19.9 & 20.2 & 28.0 \\
\hline N2 & 17.3 & 19.3 & 26.9 & 19.9 & 20.6 & 28.2 \\
\hline N3 & 17.3 & 19.5 & 29.7 & 18.9 & 20.1 & 27.8 \\
\hline $\mathbf{L S D}_{0.05}$ & N.S. & N.S. & N.S. & N.S. & N.S. & N.S. \\
\hline Prob $>$ F & 0.86 & 0.48 & 0.40 & 0.51 & 0.28 & 0.94 \\
\hline
\end{tabular}

$\dagger \mathrm{N} 1=34, \mathrm{~N} 2=67, \mathrm{~N} 3=101 \mathrm{~kg} \mathrm{~N}^{-1}$ for $\mathrm{SW}-\mathrm{WW}$-SF rotation; $\mathrm{N} 1=0, \mathrm{~N} 2=22, \mathrm{~N} 3=45 \mathrm{~kg} \mathrm{~N}^{\mathrm{N}} \mathrm{ha}^{-1}$ for SW-F rotation. 


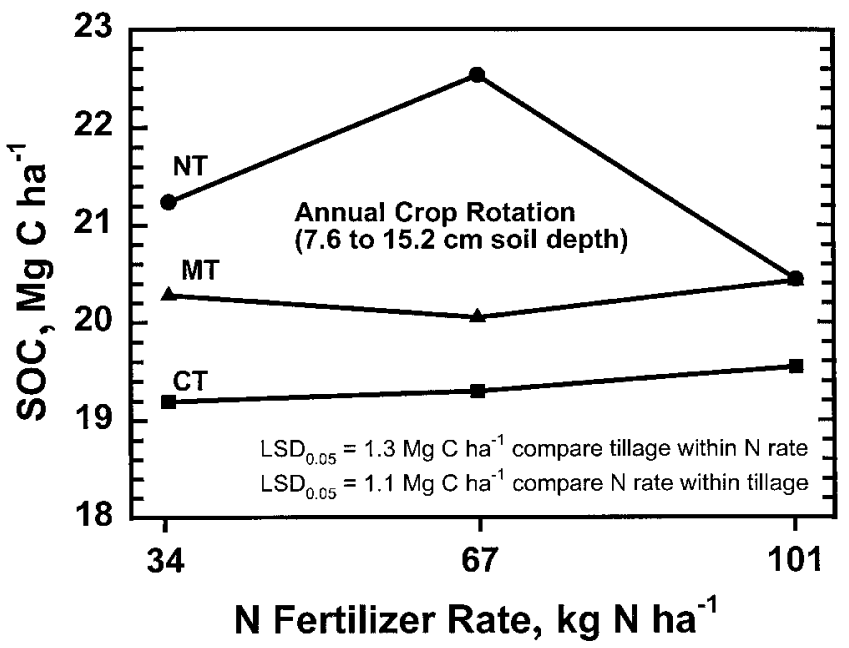

Fig. 1. Soil organic carbon (SOC) in the 7.6- to 15.2-cm depth in the annual crop (spring wheat-winter wheat-sunflower) rotation as a function of $\mathbf{N}$ fertilizer rate for the no-till (NT), minimum-till (MT), and conventional-till (CT) treatments.

cant tillage $\times \mathrm{N}$ rate interaction in the $7.6-$ to $15.2-\mathrm{cm}$ soil depth (Fig. 1). At this soil depth, NT had a higher level of SOC than with CT at the 34 and $67 \mathrm{~kg} \mathrm{ha}^{-1} \mathrm{~N}$ rates. The decrease in SOC mass with NT at the $101 \mathrm{~kg}$ ha $^{-1} \mathrm{~N}$ rate probably reflects the decrease in soil $D_{\mathrm{b}}$ shown in Fig. 2. The same trend was observed for TSN at this depth (Fig. 3), which would indicate that soil $D_{\text {b }}$ (Fig. 2) affected the measured mass of SOC at this depth for the NT treatment. Neither tillage or N fertilization rate had an effect on SOC in the 15.2- to $30.4-\mathrm{cm}$ soil depth in either cropping system.

Soil organic $\mathrm{C}$ mass in the 0 - to $15.2-\mathrm{cm}$ depth for the CT, MT, and NT systems were 4, 6, and $19 \%$ less, respectively, in the SW-F rotation compared with the $\mathrm{AC}$ rotation. The benefits of the AC system in sequestering SOC over that of SW-F system is demonstrated here along with the benefits of reducing tillage intensity to sequester SOC in the more intensive cropping system. These results are in agreement with the Canadian observations summarized by Janzen et al. (1998a) and those reported by Peterson et al. (1998) for the U.S. Great Plains.

Based on residue C measurements in 1994 and 1996, the average residue $\mathrm{C}$ content was $437 \mathrm{~g} \mathrm{~kg}^{-1}$ for SW, $432 \mathrm{~g} \mathrm{~kg}^{-1}$ for WW, and $434 \mathrm{~g} \mathrm{~kg}^{-1}$ for SF. Based on an average residue $\mathrm{C}$ for all treatments of $434 \mathrm{~g} \mathrm{C} \mathrm{kg}^{-1}$ for all crops, $\mathrm{C}$ inputs would be $\sim 15.5,16.8$, and 17.4 $\mathrm{Mg} \mathrm{C} \mathrm{ha-1} \mathrm{for} \mathrm{the} \mathrm{CT,} \mathrm{MT,} \mathrm{and} \mathrm{NT} \mathrm{treatments,} \mathrm{respec-}$ tively, for the AC system. Residue $\mathrm{C}$ inputs for the SW-F system would be $9.5,9.3$, and $8.8 \mathrm{Mg} \mathrm{C} \mathrm{ha}^{-1}$ for the CT, MT, and NT treatments, respectively.

Soil samples collected in the fall of 1983 after SF harvest had an average soil C content of 21.4, 20.5, and $14.1 \mathrm{~g} \mathrm{C} \mathrm{kg}^{-1}$ for the 0- to 7.6-, 7.6- to $15.2-$, and $15.2-$ to 30.5 -cm soil depths, respectively, as reported by Black and Tanaka (1997). The estimated mass of SOC in the fall of 1983 was $18.7,20.7$, and $28.1 \mathrm{Mg} \mathrm{C} \mathrm{ha}^{-1}$ in the 0- to 7.6-, 7.6- to 15.2-, and 15.2- to $30.5-\mathrm{cm}$ soil depths, respectively. Based on this information for 1983 and the data in Table 2 for 1996, SOC mass decreased within

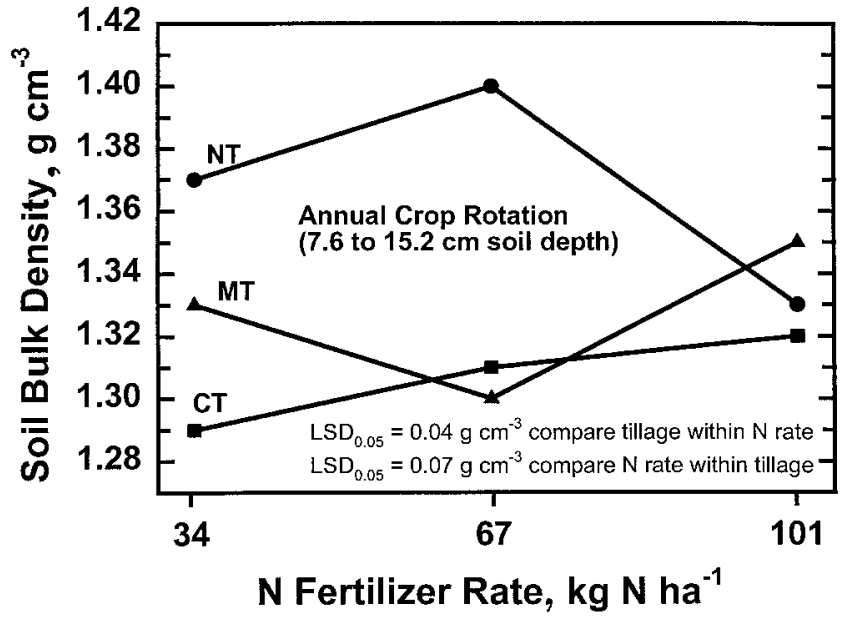

Fig. 2. Soil bulk density in the $7.6-$ to $15.2-\mathrm{cm}$ depth in the annual crop (spring wheat-winter wheat-sunflower) rotation as anction of $\mathrm{N}$ fertilizer rate for the no-till (NT), minimum-till (MT), and conventional-till (CT) treatments.

the SW-F system from the fall of 1983 to the fall of 1996. Changes in SOC mass from the fall of 1983 to the fall of 1996 in the SW-F system was $-2.4,-0.8$, and $+1.3 \mathrm{Mg} \mathrm{C}^{-1}$ for the 0 - to 7.6-, 7.6- to $15.2-$, and 15.2to $30.5-\mathrm{cm}$ soil depths, respectively, in the CT treatment. Changes in SOC mass in the MT treatments were -0.9, -0.9 , and $-0.2 \mathrm{Mg} \mathrm{C} \mathrm{ha}^{-1}$ for these same respective soil depths, while changes in SOC mass in NT treatments were $-1.3,-2.5$, and $-0.8 \mathrm{Mg} \mathrm{Cha}^{-1}$, respectively. The above comparisons assume that the two methods used for SOC analysis provided similar estimates of SOC (Bowman et al., 2002) and that the 1990 soil $D_{\mathrm{b}}$ used to calculate C mass were representative the soil $D_{\mathrm{b}}$ in 1983.

In the AC system, changes in SOC mass from Fall 1983 to Fall 1996 in CT treatments were -0.3, -1.4, and $-1.7 \mathrm{Mg} \mathrm{C} \mathrm{ha}^{-1}$ for the 0- to 7.6-, 7.6- to 15.2-, and $15.2-$ to $30.5-\mathrm{cm}$ soil depths, respectively. Changes in SOC mass in the MT treatments were $+0.8,-0.5$, and $+1.1 \mathrm{Mg} \mathrm{C} \mathrm{ha}{ }^{-1}$ for these same respective soil depths,

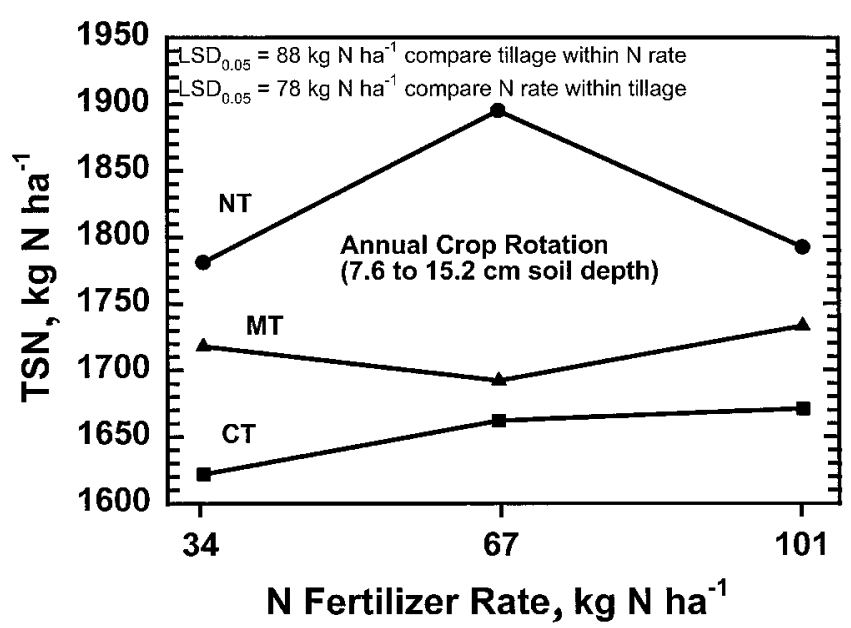

Fig. 3. Total soil N (TSN) in the 7.6- to 15.2-cm depth in the annual crop (spring wheat-winter wheat-sunflower) rotation as a function of $\mathbf{N}$ fertilizer rate for the no-till (NT), minimum-till (MT), and conventional-till (CT) treatments. 
Table 3. Total soil $\mathbf{N}$ (TSN) by soil depth after 12 yr in a spring wheat-fallow (SW-F) and an annual crop (spring wheat-winter wheatsunflower) rotation as a function of tillage and $\mathrm{N}$ rate treatments at Mandan, ND.

\begin{tabular}{|c|c|c|c|c|c|c|}
\hline \multirow[b]{3}{*}{ Treatment } & \multicolumn{3}{|c|}{ SW-F rotation } & \multicolumn{3}{|c|}{ Annual crop rotation } \\
\hline & \multicolumn{3}{|c|}{ Soil depth, cm } & \multicolumn{3}{|c|}{ Soil depth, cm } \\
\hline & $0-7.6$ & 7.6-1.52 & $15.2-30.4$ & $0-7.6$ & $7.6-15.2$ & $15.2-30.4$ \\
\hline & & & - T & 1 & 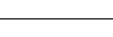 & - \\
\hline \multicolumn{7}{|l|}{ Tillage } \\
\hline CT & 1337 & 1606 & 2416 & 1539 & 1652 & 2317 \\
\hline MT & 1470 & 1608 & 2331 & 1633 & 1714 & 2468 \\
\hline NT & 1437 & 1501 & 2127 & 1752 & 1822 & 2462 \\
\hline $\mathbf{L S D}_{0.05}$ & N.S. & N.S. & N.S. & 105 & 87 & N.S. \\
\hline Prob $>$ F & 0.14 & 0.10 & 0.33 & 0.01 & 0.01 & 0.22 \\
\hline \multicolumn{7}{|l|}{ N Rate $\dagger$} \\
\hline N1 & 1380 & 1533 & 2312 & 1667 & 1707 & 2426 \\
\hline N2 & 1429 & 1579 & 2260 & 1660 & 1749 & 2447 \\
\hline N3 & 1435 & 1603 & 2302 & 1596 & 1732 & 2375 \\
\hline $\mathbf{L S D}_{0.05}$ & N.S. & N.S. & N.S. & N.S. & N.S. & N.S. \\
\hline Prob $>$ F & 0.73 & 0.22 & 0.90 & 0.62 & 0.35 & 0.81 \\
\hline
\end{tabular}

$\dagger \mathrm{N1}=34, \mathrm{N2}=67, \mathrm{N3}=101 \mathrm{~kg} \mathrm{~N}^{-1}$ har $\mathrm{SW}$-WW-SF rotation; $\mathrm{N1}=\mathbf{0}, \mathrm{N} 2=22, \mathrm{N3}=45 \mathrm{~kg} \mathrm{~N} \mathrm{ha}^{-1}$ for SW-F rotation.

while changes in SOC mass in the NT treatments were $+2.1,+0.7$, and $+0.3 \mathrm{MgC} \mathrm{ha}^{-1}$, respectively.

The above changes in SOC mass indicate that in the SW-F system, a net loss of SOC occurred from 1983 to 1996 for all tillage treatments in the 0 - to $15.2-\mathrm{cm}$ depth. Since the plot area had been in a CT more intensive cropping system than SW-F from 1951 to 1983, the loss in SOC from that initially present in the native sod may have been slower than would have occurred with a SW-F system (Jenzen et al., 1998b). Therefore, conversion to a SW-F system in 1984, where a fallow period was more frequent than in years prior to 1983, may explain some of the loss in SOC with all tillage systems within the SW-F system as a new SOC equilibrium level was being established for SW-F. The soil in 1983 was possibly at a higher level of SOC than could be sustained by the SW-F system.

In the $\mathrm{AC}$ system, there was a net loss $(-1.7 \mathrm{Mg} \mathrm{C}$ $\left.\mathrm{ha}^{-1}\right)$ in SOC with CT, a slight gain $\left(0.3 \mathrm{Mg} \mathrm{C} \mathrm{ha}^{-1}\right)$ with $\mathrm{MT}$, and a larger gain $\left(2.8 \mathrm{Mg} \mathrm{Cha}{ }^{-1}\right)$ with NT in the 0 - to $15.2-\mathrm{cm}$ soil depth. Thus, the more intensive AC system using NT was the most efficient in storing SOC in this study, with $\sim 16 \%$ of the residue $\mathrm{C}$ sequestered in the soil during the $12 \mathrm{yr}$. This compares with $\sim 2 \%$ of the residue $\mathrm{C}$ sequestered in the soil with the
MT, AC system. These residue $\mathrm{C}$ conversion efficiencies to SOC are slightly lower than those reported by Campbell et al. (2000a) for southern Saskatchewan.

\section{Soil Nitrogen}

Total soil N (TSN) in the soil depths sampled was not influenced by tillage or $\mathrm{N}$ treatment after $12 \mathrm{yr}$ within the SW-F rotation (Table 3), similar to that of SOC. In contrast, TSN increased with decreasing tillage intensity within the $\mathrm{AC}$ rotation in the 0- to 7.6- and 7.6- to $15.2-\mathrm{cm}$ soil depths, with a significant tillage $\times$ $\mathrm{N}$ interaction for the 7.6- to $15.2-\mathrm{cm}$ soil depth. This is in agreement with the increase in $\mathrm{N}$ mineralization potential with NT compared with CT reported by Wienhold and Halvorson (1999) for this site.

Although increasing $\mathrm{N}$ rate increased the amount of residue $\mathrm{N}$ returned to the soil, $\mathrm{N}$ rate did not affect TSN in the 0 - to 7.6-cm soil depth after $12 \mathrm{yr}$ in the $\mathrm{AC}$ rotation. In the $7.6-$ to $15.2-\mathrm{cm}$ soil depth, TSN was affected by tillage and $\mathrm{N}$ rate (Fig. 3 ). At this soil depth, NT had higher levels of TSN than CT at all N rates. With NT, TSN increased at the $67 \mathrm{~kg} \mathrm{ha}^{-1} \mathrm{~N}$ rate compared with the $34 \mathrm{~kg} \mathrm{ha}^{-1} \mathrm{~N}$ rate, then decreased at the $101 \mathrm{~kg} \mathrm{ha}^{-1} \mathrm{~N}$ rate. This decrease in TSN mass reflects

Table 4. Soil bulk density $\left(D_{\mathrm{b}}\right)$ by soil depth after $12 \mathrm{yr}$ in a spring wheat-fallow (SW-F) and an annual crop (spring wheat-winter wheatsunflower) rotation as a function of tillage and $\mathrm{N}$ rate treatments at Mandan, ND.

\begin{tabular}{|c|c|c|c|c|c|c|}
\hline \multirow[b]{3}{*}{ Treatment } & \multicolumn{3}{|c|}{ SW-F rotation } & \multicolumn{3}{|c|}{ Annual crop rotation } \\
\hline & \multicolumn{3}{|c|}{ Soil depth, cm } & \multicolumn{3}{|c|}{ Soil depth, cm } \\
\hline & $0-7.6$ & $7.6-15.2$ & $15.2-30.4$ & $0-7.6$ & $7.6-15.2$ & $15.2-30.4$ \\
\hline & \multicolumn{6}{|c|}{$D_{\mathrm{b}} \mathrm{g} \mathrm{cm}^{-3}$} \\
\hline \multicolumn{7}{|l|}{ Tillage } \\
\hline CT & 1.08 & 1.39 & 1.32 & 1.37 & 1.30 & 1.37 \\
\hline MT & 1.23 & 1.43 & 1.31 & 1.38 & 1.33 & 1.38 \\
\hline NT & 1.26 & 1.42 & 1.36 & 1.41 & 1.37 & 1.37 \\
\hline $\mathbf{L S D}_{0.05}$ & 0.03 & N.S. & 0.03 & N.S. & 0.03 & N.S. \\
\hline Prob $>$ F & $<\mathbf{0 . 0 1}$ & 0.09 & 0.05 & 0.11 & 0.02 & 0.41 \\
\hline \multicolumn{7}{|l|}{ N Rate } \\
\hline N1 & 1.19 & 1.40 & 1.35 & 1.41 & 1.33 & 1.39 \\
\hline N2 & 1.21 & 1.42 & 1.32 & 1.39 & 1.34 & 1.38 \\
\hline N3 & 1.17 & 1.42 & 1.33 & 1.36 & 1.33 & 1.35 \\
\hline $\mathbf{L S D}_{0.05}$ & N.S. & N.S. & N.S. & 0.03 & N.S. & N.S. \\
\hline Prob $>$ F & 0.26 & 0.46 & 0.34 & 0.03 & 0.97 & 0.24 \\
\hline
\end{tabular}

$\dagger \mathrm{N1}=34, \mathrm{N2}=67, \mathrm{N3}=101 \mathrm{~kg} \mathrm{~N} \mathrm{ha}^{-1}$ for $\mathrm{SW}-\mathrm{WW}$-SF rotation; $\mathrm{N1}=0, \mathrm{~N} 2=22, \mathrm{N3}=45 \mathrm{~kg} \mathrm{~N}^{\mathrm{Na}} \mathrm{h}^{-1}$ for $\mathrm{SW}$-F rotation. 
the decrease in soil $D_{\mathrm{b}}$ at this depth shown in Fig. 2 . Total soil $\mathrm{N}$ in the 0 - to $15.2-\mathrm{cm}$ depth was $\sim 8 \%$ less with the CT and MT system in the SW-F rotation compared with the AC rotation, and $18 \%$ less with NT after 12 yr. Total soil $\mathrm{N}$ in the $15.2-$ to $30.4-\mathrm{cm}$ depth was not affected by $\mathrm{N}$ fertilization rate or tillage in the $\mathrm{AC}$ system.

\section{Soil Bulk Density}

Soil $D_{\mathrm{b}}$ was measured in each plot to enable the calculation of mass of SOC and $\mathrm{N}$ per unit area. Soil $D_{\mathrm{b}}$ generally increased with decreased tillage intensity within the SW-F rotation at all soil depths (Table 4); however, differences were not significant in the 7.6- to $15.2-\mathrm{cm}$ depth. Soil $D_{\mathrm{b}}$ was greater with NT than with CT and MT at the 15.2- to 30.4-cm depth within the SW-F rotation. Similar trends in soil $D_{\mathrm{b}}$ were present in the 0 - to 7.6- (not significant) and 7.6- to $15.2-\mathrm{cm}$ depths within the AC rotation with regard to tillage treatment, but not at the $15.2-$ to $30.4-\mathrm{cm}$ soil depth which was not affected by tillage. The increased amount of crop residue returned to the soil with NT compared with CT in the AC rotation did not reduce soil $D_{\mathrm{b}}$ to CT levels. These data are in agreement with those reported by Grant and Lafond (1993) who found that soil $D_{\mathrm{b}}$ in the surface soil layers increased as tillage intensity decreased.

Nitrogen fertility rate generally had no effect on soil $D_{\text {b }}$ in the 0- to 7.6-cm depth within the SW-F rotation (Table 4). Soil bulk density decreased with increasing $\mathrm{N}$ rate in the 0 - to $7.6-\mathrm{cm}$ soil depth within the AC rotation. This reflects the increased amount of crop residue returned to the soil with increasing $\mathrm{N}$ rate and a likely increase in root biomass produced. This observation is in agreement with the findings reported by Halvorson et al. (1999c) from the central Great Plains who found soil $D_{\mathrm{b}}$ decreased as residue amount returned to the soil increased with increasing $\mathrm{N}$ rate.

A significant tillage $\times \mathrm{N}$ rate interaction for soil $D_{\mathrm{b}}$ was present for the 7.6- to $15.2-\mathrm{cm}$ soil depth for both cropping systems. Soil $D_{\mathrm{b}}$ in the SW-F rotation tended to increase with increasing $\mathrm{N}$ rate for the CT and MT treatments, but decrease with increasing $\mathrm{N}$ rate with NT (Fig. 4). The trends in soil $D_{\mathrm{b}}$ were similar (Fig. 2) within the AC system. The underlying cause for this interaction is unclear. None of the measured bulk densities are sufficiently high to suggest that root growth would be restricted. Soil $D_{\mathrm{b}}$ in the $15.2-$ to $30.5-\mathrm{cm}$ depth was not affected by $\mathrm{N}$ fertilization in the SW-F or AC systems (Table 4).

\section{CONCLUSIONS}

Results of this study show that SOC mass did not increase during the $12 \mathrm{yr}$ in the SW-F system, even with the use of NT. No-till tended to have the greatest loss of SOC in the 0 - to $15.2-\mathrm{cm}$ depth when compared with the other tillage treatments within the SW-F system. In contrast, NT had the greatest accumulation of SOC within the AC system for this same soil depth while SOC levels declined during the $12 \mathrm{yr}$ with CT. Nitrogen

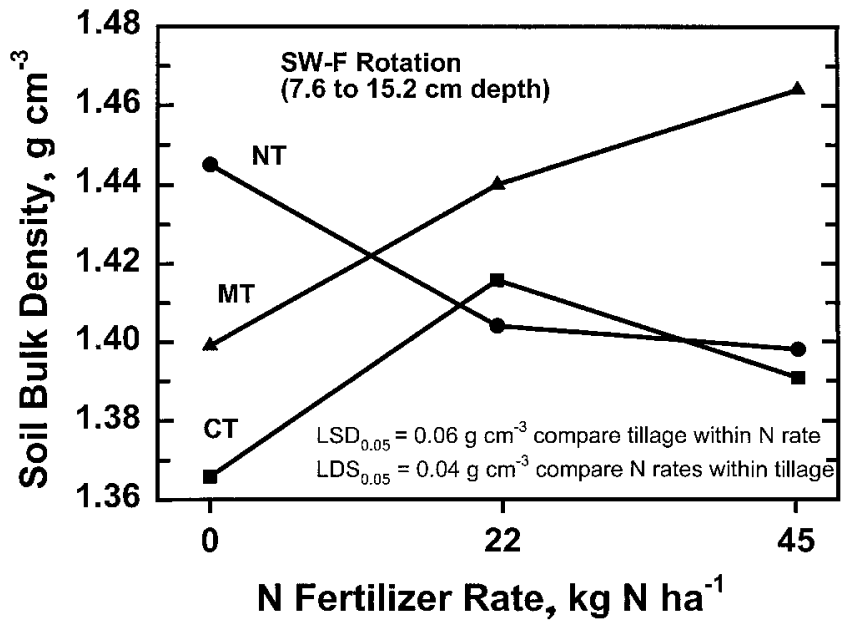

Fig. 4. Soil bulk density in the $7.6-$ to $15.2-\mathrm{cm}$ depth in the spring wheat-fallow (SW-F) rotation as a function of $\mathbf{N}$ fertilizer rate for the no-till (NT), minimum-till (MT), and conventional-till (CT) treatments.

fertilization had little effect on SOC sequestration in this study, even though crop residue production was increased by $\mathrm{N}$ fertilization in both cropping systems. Changes in TSN within tillage and $\mathrm{N}$ treatments mirrored those of SOC. Soil bulk density increased with decreased tillage intensity in both cropping systems. Soil bulk density decreased with increasing $\mathrm{N}$ rate in the 0 to $7.6-\mathrm{cm}$ soil depth within the AC system. The results suggest that continued use of a crop-fallow farming system, even with NT, may result in loss of SOC. Intensifying the cropping rotation, even including $\mathrm{SF}$ in the rotation, and utilizing NT farming practices will have a positive impact on SOC sequestration. With NT, an estimated $233 \mathrm{~kg} \mathrm{C} \mathrm{ha}^{-1}$ was sequestered each year in the AC system which included SF, compared with 25 $\mathrm{kg} \mathrm{C} \mathrm{ha}{ }^{-1}$ with MT and a loss of $141 \mathrm{~kg} \mathrm{C} \mathrm{ha}^{-1}$ with $\mathrm{CT}$. The yearly gain in SOC in the AC system with NT is similar to yearly gains in SOC reported by Campbell et al. (2000a) for well fertilized AC systems in Canada. Conversion from crop-fallow to more intensive cropping systems utilizing NT will be needed to have a positive impact on reducing $\mathrm{CO}_{2}$ loss from croplands in the U.S. northern Great Plains.

\section{ACKNOWLEDGMENTS}

The authors acknowledge the contribution of the Area IV Soil Conservation Districts in North Dakota for providing the land and assisting with financial resources to conduct this longterm study, the assistance of Dr. Gary Richardson, retired USDA-ARS Statistician, Fort Collins, CO, with the statistical analyses, and the assistance of F. Jacober, J. Harms, L. Renner, and G. Brucker in conducting the study and collecting the field and laboratory data.

\section{REFERENCES}

Aase, J.K., and G.M. Schaefer. 1996. Economics of tillage practices and spring wheat and barley crop sequence in the northern Great Plains. J. Soil Water Conserv. 51:167-170.

Bauer, A., and A.L. Black. 1981. Soil carbon, nitrogen, and bulk density comparisons in two cropland tillage systems after 25 years and in virgin grassland. Soil Sci. Soc. Am. J. 45:1166-1170. 
Bauer, A., and A.L. Black. 1994. Quantification of the effect of soil organic matter content on soil productivity. Soil Sci. Soc. Am. J. 58:185-193.

Black, A.L., and D.L. Tanaka. 1997. A conservation tillage-cropping systems study in the Northern Great Plains of the United States. p. 335-342. In E.A. Paul et al. (ed.) Soil organic matter in temperate agroecosystems-Long-term experiments in North America. CRC Press, Boca Raton, FL.

Bowman, R.A., J.D. Reeder, and B.J. Wienhold. 2002. Laboratory and field evaluations to assess the potential for carbon sequestration. Comm. Soil Sci. Plant Anal. (In press)

Campbell, C.A., B.G. McConkey, V.O. Biederbeck, R.P. Zentner, D. Curtin, and M.R. Peru. 1998. Long-term effects of tillage and fallow-frequency on soil quality attributes in a clay soil in semiarid southwestern Saskatchewan. Soil Till. Res. 46:135-144.

Campbell, C.A., B.G. McConkey, V.O. Biederbeck, R.P. Zentner, S. Tessier, and D.L. Hahn. 1997. Tillage and fallow frequency effects on selected soil quality attributes in a coarse-textured Brown Chernozem. Can. J. Soil Sci. 77:497-505.

Campbell, C.A., B.G. McConkey, R.P. Zentner, F.B. Dyck, F. Selles, and D. Curtin. 1995. Carbon sequestration in a Brown Chernozem as affected by tillage and rotation. Can. J. Soil Sci. 75:449-458.

Campbell, C.A., B.G. McConkey, R.P. Zentner, F. Selles, and D. Curtin. 1996. Long-term effects of tillage and crop rotations on soil organic $\mathrm{C}$ and total $\mathrm{N}$ in a clay soil in southwestern Saskatchewan. Can. J. Soil Sci. 76:395-401.

Campbell, C.A., and R.P. Zentner. 1993. Soil organic matter as influenced by crop rotations and fertilization. Soil Sci. Soc. Am. J. 57: 1034-1040.

Campbell, C.A., R.P. Zentner, B.-C. Liang, G. Roloff, E.C. Gregorich, and B. Blomert. 2000a. Organic C accumulation in soil over 30 years in semiarid southwestern Saskatchewan-Effect of crop rotations and fertilizers. Can. J. Soil Sci. 80:179-192.

Campbell, C.A., R.P. Zentner, F. Selles, V.O. Biederbeck, B.G. McConkey, B. Blomert, and P.G. Jefferson. 2000b. Quantifying short-term effects of crop rotations on soil organic carbon in southwestern Saskatchewan. Can. J. Soil Sci. 80:193-202.

Cihacek, L.J., and M.G. Ulmer. 1995. Estimated soil organic carbon losses from long-term crop-fallow in the northern Great Plains of the USA. p. 85-92. In R. Lal et al. (ed.) Advances in soil science: Soil management and greenhouse effect. Lewis Publishers, CRC Press, Boca Raton, FL.

Culley, J.L.B. 1993. Density and compressibility. p. 529-539. In M.R. Carter (ed.) Soil sampling and methods of analysis. Lewis Publishers, CRC Press, Boca Raton, FL.

Deibert, E.J., E. French, and B. Hoag. 1986. Water storage and use by spring wheat under conventional tillage and no-till in continuous and alternate crop-fallow systems in the northern Great Plains. J. Soil Water Conserv. 41:53-58.

Doran, J.W. 1980. Soil microbial and biochemical changes associated with reduced tillage. Soil Sci. Soc. Am. J. 44:765-771.

Farahani, H.J., G.A. Peterson, and D.G. Westfall. 1998. Dryland cropping intensification: A fundamental solution to efficient use of precipitation. Adv. Agron. 64:197-223.

Grant, C.A., and G.P. Lafond. 1993. The effects of tillage systems and crop sequences on soil bulk density and penetration resistance on a clay soil in southern Saskatchewan. Can. J. Soil Sci. 73:223-232.

Haas, H.J., W.O. Willis, and J.J. Bond. 1974. Summerfallow in the western United States. p. 12-35. In Conserv. Res. Rept. no. 17, USDA. U.S. Gov. Print. Office, Washington, DC.

Halvorson, A.D. 1990. Cropping systems and N fertilization for efficient water use in the central Great Plains. p. 117-123. In Proc. Great Plains Conserv. Tillage Symp., Bismarck, ND. 21-23 Aug. 1990. Great Plains Agric. Council (GPAC) Bull. No. 131. GPAC, Fort Collins, $\mathrm{CO}$.

Halvorson, A.D., A.L. Black, J.M. Krupinsky, and S.D. Merrill. 1999a. Dryland winter wheat response to tillage and nitrogen within an annual cropping system. Agron. J. 91:702-707.

Halvorson, A.D., A.L. Black, J.M. Krupinsky, S.D. Merrill, and D.L. Tanaka. 1999b. Sunflower response to tillage and nitrogen fertiliza- tion under intensive cropping in a wheat rotation. Agron. J. 91:637642.

Halvorson, A.D., A.L. Black, J.M. Krupinsky, S.D. Merrill, B.J. Wienhold, and D.L. Tanaka. 2000a. Spring wheat response to tillage and nitrogen fertilization in rotation with sunflower and winter wheat. Agron. J. 92:136-144.

Halvorson, A.D., A.L. Black, J.M. Krupinsky, S.D. Merrill, B.J. Wienhold, and D.L. Tanaka. 2000b. Spring wheat response to tillage and nitrogen fertilization within a crop-fallow system. Agron. J. 92:288-294.

Halvorson, A.D, and C.A. Reule. 1994. Nitrogen fertilizer requirements in an annual dryland cropping system. Agron. J. 86:315-318.

Halvorson, A.D., C.A. Reule, and R.F. Follett. 1999c. Nitrogen fertilization effects on soil carbon and nitrogen in a dryland cropping system. Soil Sci. Soc. Am. J. 63:912-917.

Halvorson, A.D., C.A. Reule, and L.S. Murphy. 2000c. No-tillage and $\mathrm{N}$ fertilization enhance soil carbon sequestration. Fluid J. 8:8-11.

Halvorson, A.D., B.J. Wienhold, and A.L. Black. 2001. Tillage and nitrogen fertilization influence grain and soil nitrogen in an annual cropping system. Agron. J. 93:836-841.

Janzen, H.H., C.A. Campbell, R.C. Izaurralde, B.H. Ellert, N. Juma, W.B. McGill, and R.P. Zentner. 1998a. Management effects on soil C storage on the Canadian prairies. Soil Till. Res. 47:189-203.

Janzen, H.H., C.A. Campbell, E.G. Gregorich, and B.H. Ellert. 1998b. Soil carbon dynamics in Canadian agroecosystems. p. 57-80. In R. Lal et al. (ed.) Soil processes and the carbon cycle. CRC Press, Boca Raton, FL.

Janzen, H.H., R.L. Desjardins, J.M.R. Asselin, and B. Grace. 1999. The health of our air: Toward sustainable agriculture in Canada. Publ. 1981/E. Agriculture and Agri-Food Canada, Ottawa, Ontario.

Lachat Instruments. 1992. Total Kjeldahl nitrogen in soil/plant. QuikChem Method No. 13-107-06-2-D. Lachat Instruments, Milwaukee, WI.

Lal, R., J. Kimble, R.F. Follett, and C.V. Cole. 1998. The potential of U.S. cropland to sequester carbon and mitigate the greenhouse effect. Ann Arbor Press Inc., Chelsea, MI.

Lal, R., R.F. Follett, and J. Kimble. 1999. Managing U.S. cropland to sequester carbon is soil. J. Soil Water Conserv. 53:374-381.

Larney, F.J., E. Bremer, H.H. Janzen, A.M. Johnston, and C.W. Lindwall. 1997. Changes in total, mineralizable and light fraction soil organic matter with cropping and tillage intensities in semiarid southern Alberta, Canada. Soil Tillage Res. 42:229-240.

Nyborg, M., E.D. Solberg, S.S. Malhi, and R.C. Izaurralde. 1995 Fertilizer N, crop residue, and tillage alter soil $\mathrm{C}$ and $\mathrm{N}$ contents after a decade. p. 93-100. In R. Lal et al. (ed.) Advances in soil science: Soil management and greenhouse effect. Lewis Publishers, CRC Press, Boca Raton, FL.

Peech, M., L.T. Alexander, L.A. Dean, and J.F. Reed. 1947. Methods of soil analysis for soil-fertility investigations. Circ. No. 757, USDA. U.S. Gov. Print. Office, Washington, DC.

Peterson, G.A., A.J. Schlegel, D.L. Tanaka, and O.R. Jones. 1996. Precipitation use efficiency as affected by cropping and tillage systems. J. Prod. Agric. 9:180-186.

Peterson, G.A., A.D. Halvorson, J.L. Havlin, O.R. Jones, D.G. Lyon, and D.L. Tanaka. 1998. Reduced tillage and increasing cropping intensity in the Great Plains conserves soil C. Soil Till. Res. 47: 207-218

Reicosky, D.C. 1997a. Tillage-induced $\mathrm{CO}_{2}$ emission from soil. Nutr. Cycl. Agroecosys. 49:273-285.

Reicosky, D.C. 1997b. Tillage methods and carbon dioxide loss: Fall versus spring tillage. p. 99-111. In R. Lal et al. (ed.) Management of carbon sequestration in soil. CRC Press, Boca Raton, FL.

SAS Institute. 1991. SAS/STAT users guide, Version 6, 4th ed. SAS Institute Inc., Cary, NC

Schepers, J.S., D.D. Francis, and M.T. Thompson. 1989. Simultaneous determination of total $\mathrm{C}$, total $\mathrm{N}$, and ${ }^{15} \mathrm{~N}$ on soil and plant material. Commun. Soil Sci. Plant Anal. 20:949-959.

Wienhold, B.J., and A.D. Halvorson. 1999. Nitrogen mineralization responses to cropping, tillage, and nitrogen rate in the northern Great Plains. Soil Sci. Soc. Am. J. 63:192-196. 